\title{
Simultaneous Degradation of Waste Phosphogypsum and Liquid Manure from Industrial Pig Farm by a Mixed Community of Sulfate-Reducing Bacteria
}

\author{
MARZENNA RZECZYCKA*, ANTONI MIERNIK and ZDZISLAW MARKIEWICZ \\ Department of Applied Microbiology, Institute of Microbiology, Warsaw University, Warsaw, Poland
}

Received 20 July 2010, revised 15 September 2010, accepted 20 September 2010

\begin{abstract}
The utilization of pig manure as a source of nutrients for the dissimilatory reduction of sulfates present in phosphogypsum was investigated. In both types of media used (synthetic medium and raw pig manure) increased utilization of sulfates with growing $\mathrm{COD} / \mathrm{SO}{ }_{4}^{2-} \mathrm{ratio}$ in the medium was observed. The percent of sulfate reduction obtained in synthetic medium was from 18 to $99 \%$, whereas the value for cultures set up in raw liquid manure was from $12 \%$ (at $\mathrm{COD} / \mathrm{SO}_{4}{ }^{2-}$ of 0.3 ) up to as high as $98 \%$ (at $\mathrm{COD} / \mathrm{SO}_{4}{ }^{2-}$ equal 3.80). Even with almost complete reduction of sulfates the percent of COD reduction did not exceed $55 \%$. Based on the results obtained it was concluded that the effectiveness of removal of sulfates and organic matter by sulfate-reducing bacteria (SRB) depends to a considerable degree on the proportion between organic matter and sulfates in the purified wastewaters. The optimal $\mathrm{COD} / \mathrm{SO}_{4}^{2-}$ ratio for the removal of organic matter was between 0.6 and 1.2 whereas the optimal ratio for the removal of sulfates was between 2.4 and 4.8 .
\end{abstract}

K e y w o rds: COD reduction, phosphogypsum, pig manure, sulfate-reducing bacteria (SRB)

\section{Introduction}

In recent years several papers have focused on the possibility of using sulfate reducing bacteria (SRB) for the anaerobic purification of industrial wastewaters, mining waters, drainage from the metallurgic industry, wastewater sediments and drainage from communal and industrial waste heaps (Dvorak et al., 1992; Hammeck and Edenborn 1992; Jong and Parry, 2006; Lens et al., 1998; 2002; Logan et al., 2005; Look et al., 1998; Silva et al., 2002; Hulshof, 2006, Alfaya et al., 2009).

Studies have also been conducted involving the use of SRB for the biodegradation of organic matter combined with: 1 - transformation of flue gas desulfurization gypsum (FGD), 2 - transformation of $\mathrm{FeSO}_{4}$ produced during the manufacture of titanium white from the flotation concentrate of titanic iron by the sulfate method, 3 - transformation of technical $\mathrm{FeSO}_{4} \times \mathrm{H}_{2} \mathrm{O}$ from ferrous metallurgy and 4 - transformation of phosphogypsum (FG) (Dvorak et al., 1992; Juszczak et al., 2002; Kaufman et al., 1996; Kowalski et al., 1990; Przytocka-Jusiak et al., 1995; 1997; Kosińska and Miśkiewicz, 2000; Rzeczycka et al., 2001, 2004; Rzeczycka and Błaszczyk, 2005).
Phosphogypsum is a hazardous waste material formed during the processing of apatites and phosphorites to yield phosphoric acids (Kowalski et al., 1990, 1996; Arocena et al., 1995; Azabou et al., 2005, 2007; Papastefanou et al., 2006). The chemical plants that apply these technologies in Poland are located in Wizów (near Boleslawiec), Police (near Szczecin) and Gdańsk. Apatite concentrates at Wizów Chemical Plant are exclusively processed from the rocks of the Khibiny massif in Kola Peninsula, Russia. Other plants process phosphorite concentrates mainly from North Africa.

The main components of phosphogypsum are hydrated calcium sulfates: gypsum $-\mathrm{CaSO}_{4} \times 2 \mathrm{H}_{2} \mathrm{O}$, halfhydrate $-\mathrm{CaSO}_{4} \times 0.5 \mathrm{H}_{2} \mathrm{O}$ and anhydrite $-\mathrm{CaSO}_{4}$ which make up $95 \%$ of the weight of phosphogypsum. Sulfate ions account for approximately $50 \%$ of the weight of phosphogypsum. The remainder includes: phosphoric acid, sulfuric acid, small amounts of $\mathrm{Fe}_{2} \mathrm{O}_{3}$, $\mathrm{Al}_{2} \mathrm{O}_{3}, \mathrm{MgO}, \mathrm{Na}_{2} \mathrm{O}, \mathrm{K}_{2} \mathrm{O}$ and the rare earth elements, the lanthanides.

Sulfate reducing bacteria are ubiquitous in anaerobic environments where organic substrates and sulfates are available. They can be encountered in aqueous and soil environments: hot springs, crude oil, sulfur deposits, natural gas outlets, estuary sludges,

\footnotetext{
* Corresponding author: M. Rzeczycka, Department of Applied Microbiology, Institute of Microbiology, Warsaw University,
} Miecznikowa 1, 02-096 Warsaw, Poland; e-mail: m.rzeczycka@biol.uw.edu.pl 
salt water reservoirs, corroding iron, the alimentary tract of animals and humans, industrial wastewaters rich in sulfates (e.g. from the chemical, metallurgic or paper industries), mining waters as well as in bioreactors (Postgate, 1984; Widdel, 1988; Hammeck and Edenborn, 1992; Deswaef et al., 1996; Hamilton, 1998; Hass and Polpraset, 1993; Cotta et al., 2003; Lens et al., 2003).

SRB are obligatory anaerobes, which obtain the energy they require from the oxidation of organic substrates, with sulfates being the terminal electron acceptors. SRB can also utilize thiosulfates or sulfites, and even elementary sulfur as electron acceptors. The preferred carbon sources for this group of microorganisms are compounds that are derived from fermentation processes, which are formed during the anaerobic degradation of organic matter: organic acids (e.g. lactate, pyruvate, formate and acetate) as well as alcohols (ethanol, propanol and butanol) (Postgate 1984; Hao et al., 1996; Rhabus et al., 2006).

The pathway of the degradation of carbon compounds by SRB depends on the interaction between this group of microorganisms and other bacteria. The addition of sulfates in the form of phosphogypsum, for example, favours domination of the system by sulfatereducing bacteria (appropriate choice of $\mathrm{COD} / \mathrm{SO}_{4}{ }^{2-}$ ratio). The activity of these bacteria results not only in the removal of sulfates (by their conversion to sulfides), but also in the breakdown of organic matter.

Phosphogypsum can be the sole source of sulfate, phosphorus and biogenic elements for these bacteria. Like other microorganisms, SRB, besides sources of carbon and energy, also require a source of nitrogen. Therefore, besides phosphogypsum, a source of organic carbon and nitrogen is also necessary. One of the waste products that could be utilized as an inexpensive source of carbon and nitrogen for SRB is raw liquid manure.

Pig manure is a production waste that arises on pig farms during animal production. For many years both aerobic and anaerobic biological manure purification methods, with accompanying production of methane, have been used. Manure is not, however, a good medium for growing bacteria because of unfavorable proportions between the basic biogens. The biotransformation of phosphogypsum, combined with anaerobic breakdown of manure could be one of the ways of reducing the amounts of both these arduous waste matters. Phosphogypsum is rich in calcium and phosphorus and poor in nitrogen, but it should be kept in mind that the introduction of large amounts of sulfates together with phosphogypsum will alter the direction of the selection of bacteria in the anaerobic purification of liquid manure and that the leading role in the last stages of purification will be played by sulfate reducing bacteria.
The end products formed in the course of the purification process are: a calcium-organic deposit (which has potential use as a fertilizer) and elemental sulfur obtained in chemical or biological pathway.

The aim of the current study was to investigate the possibility of using a community of sulfate reducing bacteria for the simultaneous biotransformation of phosphogypsum and manure from industrial pig farming, thus removing two onerous waste products at one time.

\section{Experimental}

\section{Materials and Methods}

Microorganisms. A mixed community of sulfatereducing bacteria isolated from various environments, as described elsewhere (Przytocka-Jusiak, 1995) was used.

Growth media. Sulfate-reducing bacteria were cultured in: A - synthetic minimal medium containing (in $\mathrm{g} / \mathrm{l}$ distilled water): $1.0 \mathrm{NH}_{4} \mathrm{Cl} ; 1.0-10.0$ phosphogypsum (in the form of a deposit), the source of carbon used was (g/l): sodium lactate (4.7). B - non-sterile pig manure (average chemical composition - Table I) used in this study was obtained from an industrial pig farm and stored in 51 bottles at $4-5^{\circ} \mathrm{C}$. It was diluted 3 or 6 times prior to before use. C - Liquid manure containing ( $\mathrm{g} / \mathrm{l}$ in distilled water) $1.0-10.0$ phosphogypsum (in the form of a deposit).

Phosphogypsum (Table II) was from a waste dump located in Wizów near Bolesławiec (Kowalski et al., 1990). The solubility of phosphogypsum in the above medium was approx. $36 \%$ and the concentration of phosphogypsum in the solution was therefore approx. $1.8 \mathrm{~g} / 1\left(930 \mathrm{mg} \mathrm{SO}_{4}^{2-} / \mathrm{l}\right)$. The $\mathrm{pH}$ of the medium at the time the culture was set up was 7.4. The growth of sulfate reducing bacteria was studied in the $\mathrm{COD} /$ $\mathrm{SO}_{4}{ }^{2-}$ range from 0.3 to 4.8 .

Culture conditions. The cultures were set up and maintained in $0.33 \mathrm{dm}^{3}$ bottles with rubber stoppers, $30 \mathrm{ml}$ of active mother culture was introduced through the rubber stopper using a syringe into $270 \mathrm{ml} \mathrm{me}-$ dium. The cultures were incubated in thermostat

Table I

Mean chemical composition of raw pig manure.

\begin{tabular}{|lr|}
\hline Dry weight (total) $\mathrm{mg} / \mathrm{l}$ & 30.00 \\
\hline${\mathrm{COD}\left(\mathrm{mg} \mathrm{O}_{2} / \mathrm{l}\right)}$ & 15.00 \\
\hline $\mathrm{BZT}_{5}\left(\mathrm{mg} \mathrm{O}_{2} / \mathrm{l}\right)$ & 10.50 \\
\hline Total nitrogen $($ Kjeldahl) $(\mathrm{mg} \mathrm{N} / \mathrm{l})$ & 3000.00 \\
\hline Ammonia nitrogen $(\mathrm{mg} \mathrm{N} / \mathrm{l})$ & 1600.00 \\
\hline Total phosphorus $(\mathrm{mg} \mathrm{P} / \mathrm{l})$ & 650.00 \\
\hline $\mathrm{pH}$ & 7.60 \\
\hline
\end{tabular}


Table II

Chemical composition of phosphogypsum from Wizów.*

\begin{tabular}{|l|c|c|}
\hline Component & Sample 9/2 & $\begin{array}{c}\text { Ranges of variation of the chemical } \\
\text { composition of phosphogypsum } \\
\text { from Wizów }\end{array}$ \\
\hline $\mathrm{CaO}$ & 29.23 & $29.23-30.49$ \\
\hline $\mathrm{SO}_{3}$ & 41.95 & $41.95-43.20$ \\
\hline $\mathrm{Fe}_{2} \mathrm{O}_{3}$ & 0.13 & $0.08-0.20$ \\
\hline $\mathrm{Al}_{2} \mathrm{O}_{3}$ & 0.20 & $0.20-0.29$ \\
\hline $\mathrm{MgO}$ & 0.05 & $0.03-0.06$ \\
\hline $\mathrm{SrO}$ & 1.53 & $1.53-1.82$ \\
\hline $\mathrm{BaO}$ & 0.04 & $0.01-0.06$ \\
\hline $\mathrm{Na}{ }_{2} \mathrm{O}$ & 0.31 & $0.31-0.56$ \\
\hline $\mathrm{K}_{2} \mathrm{O}$ & 0.10 & $0.08-0.11$ \\
\hline $\mathrm{P}_{2} \mathrm{O}_{5}$ & 2.20 & $1.26-3.03$ \\
\hline $\mathrm{Ln}_{2} \mathrm{O}_{3}$ & 0.61 & $0.11-0.65$ \\
\hline $\mathrm{H}_{2} \mathrm{O}$ & 20.40 & $19.80-20.50$ \\
\hline $\mathrm{F}_{2}$ & 0.50 & $0.30-0.65$ \\
\hline
\end{tabular}

* major components, data given as weight $\%$

for $8-15$ days at $30^{\circ} \mathrm{C}$. When the culture reached its maximum activity it was introduced into fresh medium with the same composition. Three consecutive passages in the same medium (minimal medium or pig manure) were made.

Determinations. Sulfides were determined using the iodometric method with Lugol's solution $(0.05 \mathrm{M})$ and sodium thiosulfate $(0.05 \mathrm{M})$ against starch $(0.5 \%)$ as an indicator. Chemical oxygen demand (COD) was determined as described in (Malina, 1967).
Calculations. Reduction of sulfates was calculated according to the formula:

$$
\mathrm{R}_{\mathrm{SO} 4}=\left(\mathrm{HS}_{\text {tmax }}^{-}-\mathrm{HS}_{\text {to }}^{-}\right) \times 2,91 / \mathrm{t}_{\max }-\mathrm{t}_{\mathrm{o}} \text {, }
$$

where: $-\mathrm{R}-$ maximum reduction of sulfates ( $\left.\mathrm{mg} \mathrm{SO}_{4}{ }^{2-} / 1\right) ; \mathrm{HS}^{-} \mathrm{t}_{\max }$ - concentration of sulphites at time $t_{\text {max }} ; \mathrm{HS}^{-}$- concentration of sulfites at time $\mathrm{t}_{\mathrm{o}}$.

The $\mathrm{COD} / \mathrm{SO}_{4}{ }^{2-}$ ratio was calculated as the ratio of $\mathrm{COD}$ and concentration of sulfates in the medium. The coefficient of carbon oxidized was calculated from the proportion between COD reduction and amount of reduced sulfates. The maximal rate of sulfate reduction $\left(\mathrm{V}_{\max } \mathrm{SO}_{4}^{2-}\right)$ was calculated based on the maximum rate of sulfate reduction ( $\mathrm{mg} \mathrm{SO}_{4}^{2-} / 1 \mathrm{x}$ day).

\section{Results and Discussion}

The growth of a community of sulfate reducing bacteria (SRB) in minimal medium and raw manure was examined. The source of the sulfates used was phosphogypsum: an industrial waste that is formed in large quantities during the production of phosphoric acid. Phosphogypsum has been shown to be a good electron acceptor for SRB (Kowalski et al., 1996). The solubility of phosphogypsum in the above medium was approx. $36 \%$ and the concentration of phosphogypsum in the solution was therefore approx. $1.8 \mathrm{~g} / 1$ (930 $\left.\mathrm{mg} \mathrm{SO}_{4}{ }^{2-} / 1\right)$. Such a high amount of sulfate ions allows for the high activity of sulfate reducing bacteria (ca. $400 \mathrm{mg} \mathrm{SO}_{4}{ }^{2-} / 1 \times$ day) (Fig. 1). The carbon source for these bacteria in minimal medium was sodium lactate and in the case of liquid manure the organic compounds present in it.
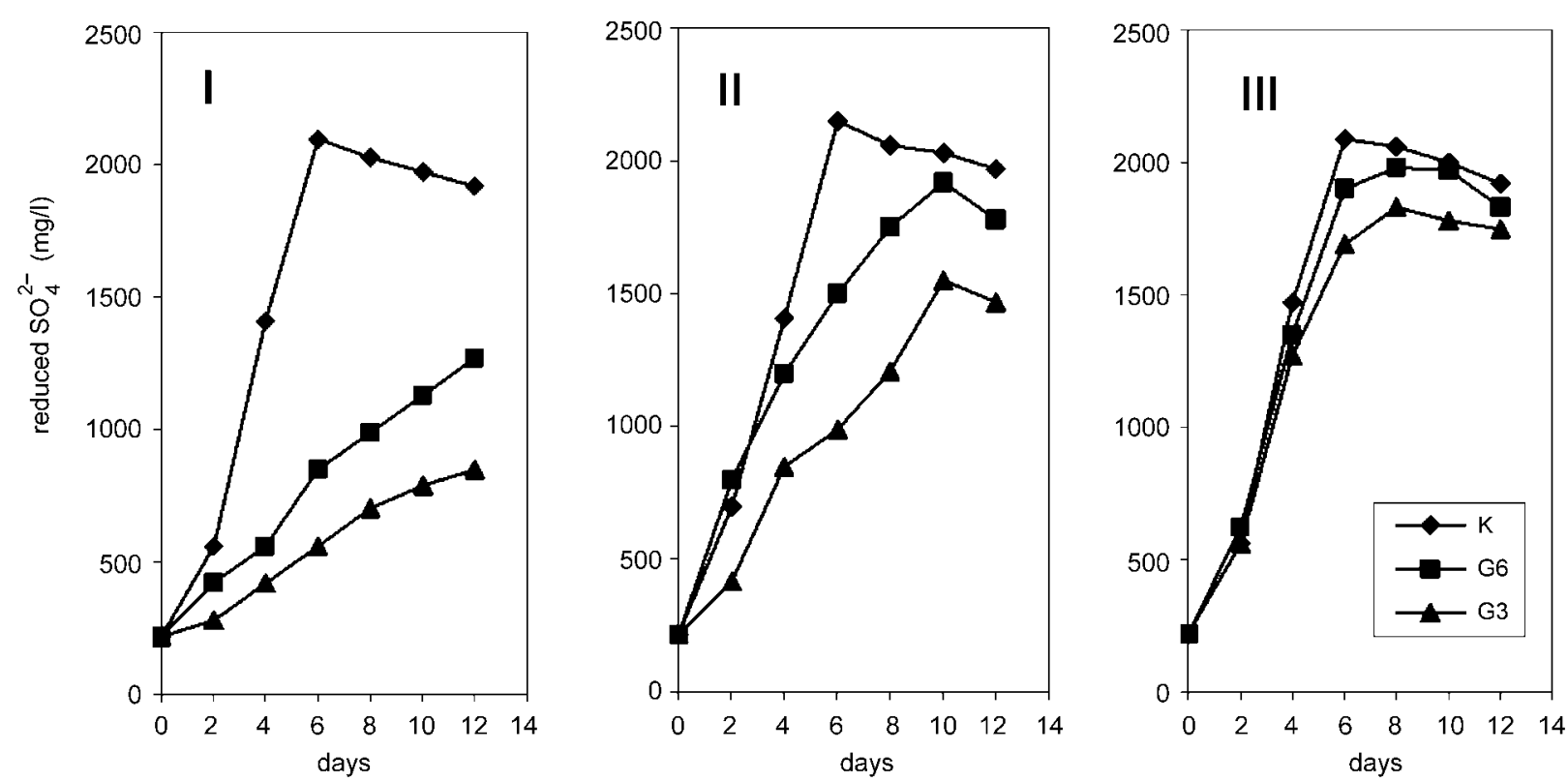

Fig. 1. Reduction of sulfates in medium with phosphogypsum and sodium lactate (K) and in liquid manure diluted six-fold (G6) or three-fold (G3) in consecutive passages of sulfate-reducing bacteria. I, II, III - consecutive passages. 
Considerable differences in the development of SRB in medium minimal and diluted manure were observed (Fig. 1). In the first passage the reduction of sulfates in pig manure diluted six-fold (COD approx. $2500 \mathrm{mg} \mathrm{O} / 1$ ) and three-fold (COD approx. $5000 \mathrm{mg}$ $\left.\mathrm{O}_{2} / 1\right)$ reached its maximal value only after 12 days of incubation (1270 and $850 \mathrm{mg} \mathrm{SO}{ }_{4}^{2-} / 1$, respectively) whereas in parallel culture in minimal medium $2100 \mathrm{mg} \mathrm{SO}{ }_{4}^{2-} / 1$ were reduced after only 6 days of incubation. This is easy to explain because the studied community of bacteria had been repeatedly grown in minimal medium. The necessity of considerably diluting liquid manure in order to achieve simultaneous phosphogypsum biodegradation would be economically unprofitable and for that reason an attempt was made to adapt the bacteria to the raw manure. The activity of the bacteria grew considerably in the second and third passages (Fig. 1B and C). In three-fold diluted pig manure the reduction of sulfates in the second passage after 10 days was $1550 \mathrm{mg} \mathrm{SO}_{4}^{2-} / 1$, and after a consecutive (third) passage it was comparable to that obtained in culture in minimal medium and raw manure diluted six-fold (Fig. 1C).

It is thus possible, when using pig manure as a culture medium for bacteria reducing sulfates in phosphogypsum, to strongly limit the dilution of the manure with water.

The use of pig manure as a source of carbon for SRB also requires determining the appropriate proportion between the concentration of electron donor and concentration of electron acceptor in the form of sulfates in phosphogypsum. In the subsequent stage of our studies the development of a community of sulfate reducing bacteria in minimal medium and raw manure diluted three-fold, with $\mathrm{COD} / \mathrm{SO}_{4}{ }^{2-}$ ratio between 0.3 and 4.8 , was examined.

The amount of sulfates reduced depended on the $\mathrm{COD} / \mathrm{SO}_{4}{ }^{2-}$ ratio in the medium (Fig. 2). It was the highest when the ratio was $0.8-1.2$ and successively

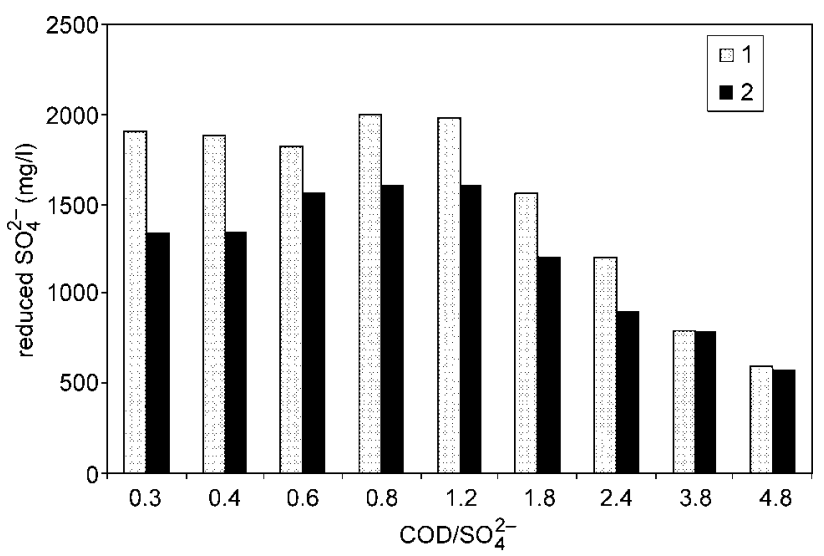

Fig. 2. Maximum reduction of $\mathrm{SO}_{4}{ }^{2-}$ in cultures of a community of sulfate-reducing bacteria in minimal medium (1) and raw manure (2) with varying $\mathrm{COD} / \mathrm{SO}_{4}{ }^{2-}$ ratio. dropped as the ratio increased. Reduction in the amount of reduced sulfates with increase of $\mathrm{COD} /$ $\mathrm{SO}_{4}{ }^{2-}$ ratio (from 0.30 to 4.70 ) was also observed by Kosińska and Miśkiewicz $(1997,1999)$ in cultures of Desulfovibrio desulfuricans maintained in liquid pig manure. Studies by Song et al. (1998) on electroplating wastewaters inoculated with a community of SRB showed that the amount of sulfates reduced dropped with increasing $\mathrm{COD} / \mathrm{SO}_{4}{ }^{2-}$ ratio in the medium from 0.33 to 1.21 .

The rate of the reduction of sulfates (Fig. 3) in minimal medium and raw manure was the highest when the $\mathrm{COD} / \mathrm{SO}_{4}{ }^{2-}$ ratio in both studied media was 0.3 (300 and $180 \mathrm{mg} \mathrm{SO}_{4}{ }^{2-} / 1 \mathrm{x}$ day, respectively). With increasing $\mathrm{COD} / \mathrm{SO}_{4}{ }^{2-}$ ratio in the medium the rate gradually declined. Song et al. (1998) observed accelerated rate of reduction of sulfates with increase of $\mathrm{COD} / \mathrm{SO}_{4}{ }^{2-}$ ratio from 0.33 to 1.21 , but the rate of violently decreased when the latter value was exceeded. Kosińska and Miśkiewicz $(1997,1999)$ in their studies on the growth of Desulfovibrio desulfuricans in raw liquid manure observed that the rate of reduction of sulfates was the highest at $\mathrm{COD} / \mathrm{SO}_{4}{ }^{2-}=0.8-1.3$.

Sulfate reducing bacteria are able to utilize various carbon sources. However, sodium lactate, which we used as the sole carbon source in minimal medium, is considered the best carbon source for these bacteria (Hao et al., 1996; Postgate, 1984; Rhabus et al., 2006). The second of the growth media used - fermented pig manure - contains various organic compounds, both high and low molecular weight ones. The specific chemical composition of pig manure is the outcome of the action of different groups of microorganisms, especially of bacteria conducting hydrolysis and fermentation processes (Cotta et al., 2003; Zhu, 2000; Logan et al., 2005). Pig manure is also rich in mineral compounds and contains high concentrations of inorganic nitrogen, phosphorus and magnesium as well as microelements. Bacteria growing in pig

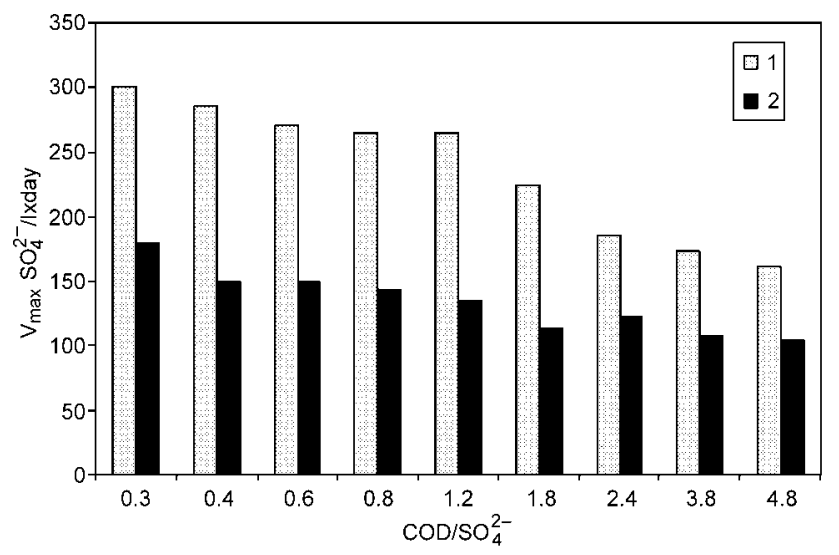

Fig. 3. Rate of sulfate reduction $\left(\mathrm{V}_{\max } \mathrm{SO}_{4}^{2-}\right)$ in cultures of a community of sulfate-reducing bacteria in minimal medium (1) and raw manure (2) with varying $\mathrm{COD} / \mathrm{SO}_{4}{ }^{2-}$ ratio. 


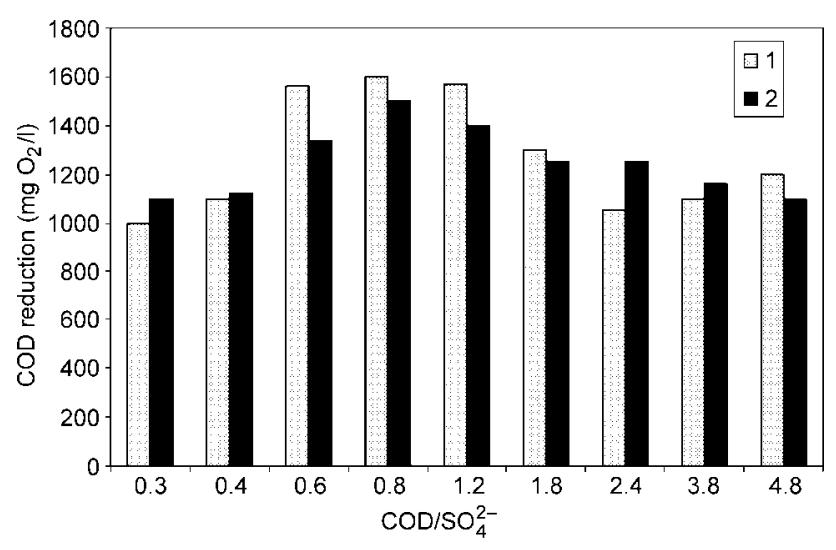

Fig. 4. COD reduction $\left(\mathrm{mg} \mathrm{O}_{2} / 1\right)$ in cultures of a community of sulfate-reducing bacteria in minimal medium (1) and raw manure (2) with varying $\mathrm{COD} / \mathrm{SO}_{4}{ }^{2-}$ ratio.

manure utilize first of all those compounds that are the simplest and easiest to assimilate. The studied cultures in our experiments were maintained under nonsterile conditions and moreover, they were inoculated with a community of bacteria in which accompanying microflora, competing with sulfate reducing bacteria for carbon sources, was always present.

Literature data indicate that the growth and domination of individual groups of microorganisms in such communities depends not only on the carbon source used, but also on the $\mathrm{COD} / \mathrm{SO}_{4}{ }^{2-}$ ratio in the medium. The main group competing with SRB are methanogenic archeons. At $\mathrm{COD} / \mathrm{SO}_{4}{ }^{2-}$ ratio lower than 1.7 SRB dominate, within the range 1.7-2.7 both groups of organisms co-dominate, and when the ratio exceeds 2.7 methanogenic archeons take over. According to Hao et al. (1996) the only group present in the medium at $\mathrm{COD} / \mathrm{SO}_{4}{ }^{2-}$ ratio lower than 0.4 are sulfate-reducing bacteria.

The $\mathrm{COD} / \mathrm{SO}_{4}{ }^{2-}$ ratio in the medium in the studies presented in this paper was $0.3-4.8$. Consequently, in cultures with $\mathrm{COD} / \mathrm{SO}_{4}{ }^{2-}$ ratio higher than 1.7 , the significant role of methanogenic archeons could be anticipated. The highest COD reduction in cultures in minimal medium or pig manure was observed at the $\mathrm{COD} / \mathrm{SO}_{4}{ }^{2-}$ ratios of 0.6 and 1.2, respectively (Fig. 4). The effectiveness of the removal or organic carbon (similarly to the rate of sulfate reduction) dropped with increase of $\mathrm{COD} / \mathrm{SO}_{4}{ }^{2-}$ ratio in the medium to values above 1.2. This is understandable because the concentration of sulfates in the medium that could serve as electron acceptors for SRB decreases. Somewhat different results were obtained by Kosińska and Miśkiewicz (1999) for Desulfovibrio desulfuricans cultures in raw liquid manure and wastewaters from a yeast production plant. The authors obtained the best results for the removal of organic matter at $\mathrm{COD} /$ $\mathrm{SO}_{4}{ }^{2-}$ ratio in the medium of 0.4-0.8. Vossoughi et al. (2003) demonstrated that a decrease of $\mathrm{COD} / \mathrm{SO}_{4}{ }^{2-}$

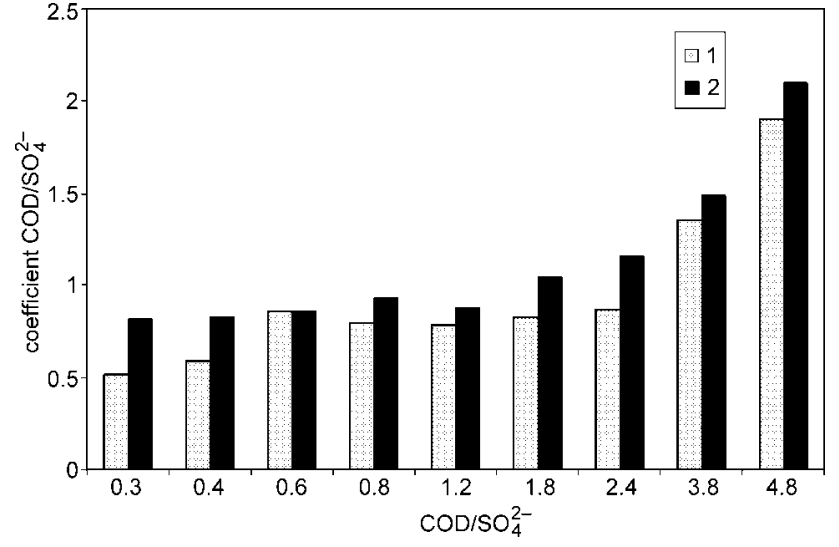

Fig. 5. Value of COD/ $/ \mathrm{SO}_{4}{ }^{2-}$ coefficient in cultures of a community of sulfate-reducing bacteria in minimal medium (1) and raw manure (2) with varying $\mathrm{COD} / \mathrm{SO}_{4}{ }^{2-}$ ratio.

ratio (from 16.7 to 6.0 ) had little positive effect on removal efficiency. This behavior could be attributed to the presence of the numerous sulfate-reducing bacteria, which are able to utilize organic carbon.

Based on the reaction: $2 \mathrm{C}+\mathrm{SO}_{4}{ }^{2-}+\mathrm{H}_{2} \mathrm{O} \rightarrow \mathrm{H}_{2} \mathrm{~S}$ $+2 \mathrm{HCO}_{3}^{-}$Maree and Strydom (1987), Hao et al. (1996) calculated that the theoretical $\mathrm{COD} / \mathrm{SO}_{4}{ }^{2-}$ ratio should be $0.67 \mathrm{mg} \mathrm{COD} / \mathrm{mg} \mathrm{SO}_{4}{ }^{2-}$. Stoichometrically, $1200 \mathrm{mg}$ COD is required for the reduction of $1800 \mathrm{mg}$ sulfate. However, this coefficient is usually higher and depending on the carbon source and type of culture, it ranged from 0.7 to 1.5 . In the studies presented in this paper the value of the coefficient of oxidized carbon to reduced sulfates in minimal medium was from 0.52 to 1.8 , whereas in pig manure it was higher, from 0.82 to 2.0 (Fig. 5). The high value of the discussed coefficient explicitly indicates the utilization of the organic compounds present in the medium by accompanying microflora that occurs in the pig manure in large numbers.

In the studied cultures on mineral medium and three-fold diluted raw pig manure an increase in $\mathrm{COD} / \mathrm{SO}_{4}{ }^{2-}$ ratio in the medium was observed to be accompanied by increased utilization of sulfates (Fig. 6). The reduction of sulfates in cultures set up in raw liquid manure with $\mathrm{COD} / \mathrm{SO}_{4}{ }^{2-}$ of 0.3 was $12 \%$ and with $\mathrm{COD} / \mathrm{SO}_{4}{ }^{2-}$ of 3.8 was as high as $97 \%$. Similar results were obtained by Kosińska and Miśkiewicz (2000; 2005) for Desulfovibrio desulfuricans grown in medium with pig manure. The authors observed, however, a somewhat higher percentage of sulfate reduction (approx. 46\%) at low $\mathrm{COD} / \mathrm{SO}_{4}{ }^{2-}$ ratio in the medium. It should be pointed out, however, that even with almost complete reduction of sulfates (e.g. $97 \%$ for pig manure and $99 \%$ in minimal medium) COD reduction never exceeded 55\% (Fig. 6).

Based on the data obtained in this study it can be concluded that the effectiveness of the removal of sulfates and organic compounds by a mixed community 

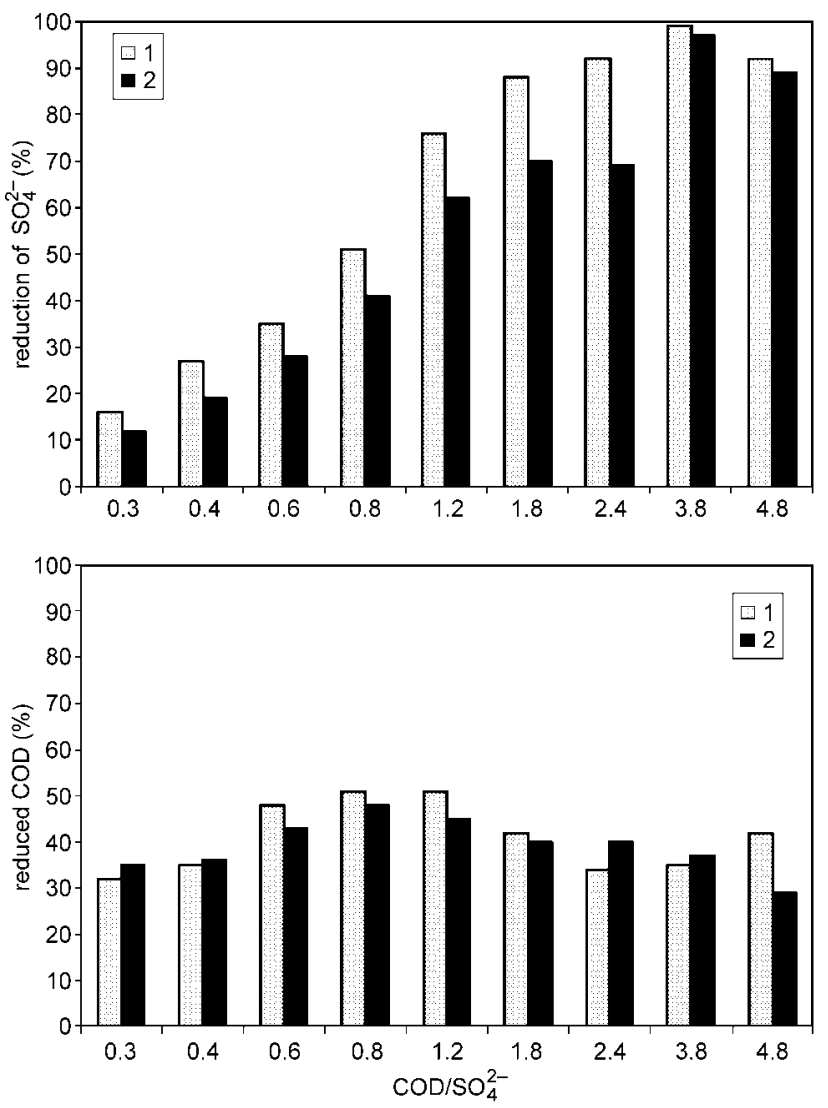

Fig. 6. Reduction of $\mathrm{SO}_{4}{ }^{2-}(\%)$ and $\mathrm{COD}$ reduction (\%) in cultures of a community of sulfate-reducing bacteria in minimal medium (1) and raw manure (2) with varying $\mathrm{COD} / \mathrm{SO}_{4}{ }^{2-}$ ratio.

of sulfate reducing bacteria depends to a significant degree on the proportion between organic matter and sulfates in the purified wastes. The $\mathrm{COD} / \mathrm{SO}_{4}{ }^{2-}$ ratio that is optimal for the removal of organic matter differs, however, from that being optimal for the removal of sulfates and is $0.8-1.2$ and $2.4-4.8$, respectively.

The studies presented here, conducted using synthetic medium and raw liquid manure, are consistent with earlier observations regarding the possibility of using sulfate reducing bacteria for simultaneously removing sulfate ions and organic matter from varied wastewaters. Wastewaters are rarely characterized by adequate ratio of organic matter content to that of sulfates from the viewpoint of effective course of purification. Consequently, besides appropriate $\mathrm{pH}$, salinity, temperature or $\mathrm{C}: \mathrm{N}$ ratio, also the $\mathrm{COD} / \mathrm{SO}_{4}{ }^{2-}$ ratio is an indicator of crucial importance. However, our results are in strong support of the future potential of employing SRB for the removal of hazardous pig manure and phosphogypsum in a single process.

\section{Literature}

Alfaya F., M. Cuenca-Sanchez, F. Garcia-Orenes and P.N.L. Lens. 2009. Endogenous and bioaugmented sulfate reduction in calcareous gypsiferous soils. Environ. Technol. 30: 1305-1312.
Arocena J.M., P.M. Rutherford and M.J. Dudas. 1995. Heterogeneous distribution of trace elements and fluorine in phosphogypsum by-product. Sci. Total. Environ. 162: 149-160.

Azabou S., T. Mechichi and S. Sayadi. 2005. Sulfate reduction from phosphogypsum using mixed culture of sulfate reducingbacteria. Int. Biodeter. Biodegr. 56: 236-242.

Azabou S., T. Mechichi and S. Sayadi. 2007. Zinc precipitation by heavy-metal tolerant sulfate-reducing bacteria enriched on phosphogypsum as a sulfate source. Miner. Eng. 20: 173-178.

Cotta M.A., T.R. Whitehead and R.L. Zeltwanger. 2003. Isolation, characterization and comparison of bacteria from swine faeces and manure storage pits. Environ. Microbiol. 5: 737-745. Deswaef S., T. Salmon, S. Hiligsmann, X. Taillieu, N. Milande, Ph. Thonart and M. Crine. 1996. Treatment of gypsum waste in a two stage anaerobic reactor. Water Sci. Technol. 34: 367-334. Dvorak D.H., R.S. Hedin, H.M. Edenborn and P.E. McIntire. 1992. Treatment of metal-contaminated water using bacterial sulfate reduction: results from pilot scale reactors. Biotechnol. Bioeng. 40: 609-616.

Hamilton W.A. 1998. Bioenergetics of sulfate-reducing bacteria in relation to their environment impact. Biodegradation 9: 201-212. Hammeck R.W. and H.M. Edenborn. 1992. The removal of nickel from mine waters using bacterial sulfate reduction. Appl. Microbiol. Biotechnol. 37: 674-678.

Hao O.J., J.M. Chen, L.J. Huang and R.L. Buglass. 1996. Sulfate-reducing bacteria. Crit. Rev. Env.Sci. Tech. 26: 155-187.

Hass C.N. and Polpraset C. 1993. Biological sulfide prestripping for metal and COD removal. Water Environ. Res. 65, 645-649.

Hulshof A.H.M. 2006. Evaluation of in situ layers for treatment of acid mine drainage: a field comparison. Water Res. 40: 1816-1826. Jong T. and D.L. Parry. 2006. Microbial sulfate reduction under sequentially acidic conditions in an upflow anaerobic packed bed bioreactor. Water Res. 40: 2561-2571.

Juszczak A., M. Waligórska, K. Seifert, A. Meller, M. Habrych and F. Domka. 2002. The effect of phosphogypsum on the activity of Desulfotomaculum ruminis in lactate medium. Pol. J. Environ. Stud. 11: 361-366.

Kaufman E.N., M.H. Little and P.T. Selvaraj. 1996. Recycling of FGD gypsum to calcium carbonate and elemental sulfur using mixed sulfate-reducing bacteria with sewage digest as a carbon source. J. Chem. Tech. Biotechnol. 66: 356-374.

Kosińska K. and T. Miśkiewicz. 1997. Degradation of organic substances by Desulfovibrio desulfuricans in liquid manure from industrial pig farming. Biotechnol. Lett. 19: 515-519.

Kosińska K. and T. Miśkiewicz. 1999. Upgrading the efficiency of dissimilatory sulfate reduction by Desulfovibrio desulfuricans via adjustment of the $\mathrm{COD} / \mathrm{SO}_{4}$ ratio. Biotechnol. Lett. 21: 299-302.

Kosińska K. and T. Miśkiewicz. 2000. Simultaneous degradation of waste $\mathrm{FeSO}_{4}$ with liquid manure from industrial pig farming by Desulfovibrio desulfuricans. Environ. Technol. 21: 585-589

Kosińska K. and T. Miśkiewicz. 2005. Enhancement of continuous biodegradation on sulfates and organic pollutants by Desulfovibrio desulfuricans via biomass recirculation. Electron J. Pol. Agric. Univ. 8(3), 23. (www.ejpau.media.pl/volume8/issue3/ art-23.html)

Kowalski W., M. Błaszczyk, R. Mycielski, M. Przytocka-Jusiak and M. Rzeczycka. 1996. Microbiological recovery of lanthanides from phosphogypsum waste. Applied Mineralogy Proceedings of the 5th International Congress on Applied Mineralogy in the Minerals Industry. Warsaw University of Technology, 2-5 June.

Kowalski W., J. Parafiniuk and M. Stępisiewicz. 1990. Mineralogy and geochemistry of phosphogypsum from Wizów. Chemical Plant heaps (in Polish). Arch. Mineral. 45: 115-134.

Lens P.LN., A. Visser, A. Janssen, P.L. Hulshoff and G. Lettinga. 1998. Biotechnological treatment of sulfate rich wastewaters. Crit. Rev. Env. Sci. Tech. 28: 41-88. 
Lens P.LN., M. Vallero, G. Esposito and M. Zandvoort. 2002. Perspectives of sulfate reducing bioreactors in environmental biotechnology. Rev. Environ. Sci. Biotechnol. 1: 311-325.

Lens P.L.N., R. Klijn, J.B. van Lier and G. Lettinga. 2003. Effect of specific gas loading rate on thermophilic $\left(55^{\circ} \mathrm{C}\right)$ acidifying ( $\mathrm{pH} 6)$ and sulfate reducing granular sludge reactors. Water Res. 37: 1033-1047.

Logan MV., K.F. Rerdon and L.A. Figueroa. 2005. Microbial community activation during establishment performance, and decline of bench scale passive treatment systems for mine drainage. Water Res. 39: 4537-4551.

Look W., P. Hulshoff, P.N.L. Lens, A.J.M. Stams and G. Lettinga. 1998. Anaerobic treatment of sulfate-rich wastewaters. Biodegradation 9: 213-224.

Malina J. 1967. Chemical oxygen demand. Analytical procedures and methods. Prepared for Poland Project. 26 WHO. University of Texas at Austin.

Maree J.P. and W.F. Strydom. 1987. Biological sulfate removal from industrial effluent in an upflow packed bed reactor. Water Res. 21: 141-146.

Papastefanou C., S. Stoulos, A. Ioannidou and M. Manolopoulou. 2006. The application of phosphogypsum in agriculture and the radiological impact. J. Environ. Radioact. 89: 188-198.

Postgate J.R. 1984. The Sulfate Reducing Bacteria. $2^{\text {nd }}$ ed. Cambridge University Press, Cambridge.

Przytocka-Jusiak M., W. Kowalski, M. Rzeczycka, M. Błaszczyk and R. Mycielski. 1995. Microbiological phosphogypsum transformation products in thermophilic anaerobic cultures (in Polish). Biotechnologia 29: 103-112.

Przytocka-Jusiak M., M. Rzeczycka, E. Ponichtera and R. Mycielski. 1997. Degradation of benzene by thermophilic sulfate reducing bacteria (in Polish). Materials from the V Polish National
Science and Technology Symposium "Environmental Biotechnology". Wrocław.

Rhabus R., T.A. Hansen and F. Widdel. 2006. Dissimilatory sulfate and sulfur-reducing prokaryotes, pp. 659-768. In: M. Dworkin, S. Falkow, E. Rosenberg, K.H. Schleifer and E. Stackebrandt (eds.), The Procaryotes. Vol. 2. Springer, New York.

Rzeczycka M., R. Mycielski, W. Kowalski and M. Gałązka. 2001. Biotransformation of phosphogypsum in media containing different forms of nitrogen. Acta Microbiol. Polon. 50: 281-289.

Rzeczycka M., A. Suszek and M. Blaszczyk. 2004. Biotransformation of phosphogypsum by sulfate-reducing bacteria in media containing different zinc salts. Pol. J. Environ. Stud. 13: 209-217.

Rzeczycka M. and M. Błaszczyk. 2005. Growth and activity of sulfate-reducing bacteria in media containing phosphogypsum and different sources of carbon. Pol. J. Environ. Stud. 14: 891-895.

Silva A.J., M.B. Varesche, E. Foresti and M. Zaiat. 2002. Sulfate removal from industrial wastewater using a packed-bed anaerobic reactor. Process Biochem. 37: 927-935.

Song Y. Ch., B.Ch. Piak, H.S. Shin and S.J. La. 1998. Influence of electron donor and toxic materials on the activity of sulfatereducing bacteria for the treatment of electroplating wastewater. Water Sci. Technol. 38: 187-194, 1998.

Vossoughi M., M. Shakeri and I. Alemzadeh. 2003. Performance of anaerobic baffled reactor treating synthetic wastewater influenced by decreasing $\mathrm{COD} / \mathrm{SO}_{4}$ ratios. Chem. Eng. Process. 42: 811-816.

Widdel F. 1988. Microbiology and Ecology of Sulfate and SulfurReducing Bacteria, pp. 469-585. In: Zehnder A.J.B. (ed.), Biology of Anaerobic Microorganisms. Wiley \& Sons, New York. Zhu J. 2000. A review of microbiology in swine manure odor control. Agr. Ecosys. Environ. 78: 93-106. 